\title{
Local Government and Illegal Drilling
}

\author{
Marsudi Utoyo \\ STIH Sumpah Pemuda Palembang \\ Palembang, Indonesia \\ Mutoyo68@gmail.com
}

\begin{abstract}
Until early 2018, the Ministry of ESDM noted, the number of old oil wells Indonesia there are 13,824 wells. The Government of Indonesia offers the management of the old wells to the Regional Owned Enterprises and the Village Unit Cooperatives. But still minimal interest BUMD and KUD to manage the old wells. Among the old wells are spread in South Sumatera 3,623 wells, Thousands of old wells were closed temporarily because they were considered uneconomical. The need for cheap fuel is the main reason for people to do illegal drilling.
\end{abstract}

What matters in this paper is What is the cause of illegal drilling which is still rampant up to now, and What is the result of illegal drilling that does not match Standard Operating Procedure (SOP).

Research method in research using normative method, research conducted is descriptive that describes the symptoms in society society to a case studied, approach done that is qualitative approach which is research procedure yielding descriptive data.

The results showed that in district Musibanyuasin the management of old wells based on Perda district Musibanyuasin No. 26 of 2007 on old wells, which became the cause of illegal drilling is economic problems and needs, management of old wells themselves are also followed by illegal drilling which is not according to the Standard Operating Procedure (SOP), which led to a violation of law, environmental damage, fire wells old who resulted in casualties.

Conclusion, the reason for the illegal illegal drilling due to the economy and the necessities of life, the old well management activity is based on local regulations so that the management of the old well is also overshadowed by illegal drilling activities that are not in accordance with $\mathrm{Standard}$ Operating Procedure (SOP) of S KK Migas.

Recommendation, Pertamina party must permanently close / not close operation so that old oil wells can not be used as illegal drilling.

Keywords—illegal drilling, old well, SKK Migas

\section{INTRODUCTION}

Indonesia is endowed with God's abundant natural resources. From the natural resources of energy, besides being known to have oil and gas reserves that are managed in a modern way, Indonesia also has abundant reserves of oil and gas resources that have been traditionally managed. Or commonly called the old oil wells.
Quoted from the Director General of Oil and Gas (Oil and Gas) Ministry of Energy and Mineral Resources, Indonesia has no less than 13,824 old oil wells scattered in various regions of this country. Of these, 745 are active, while 13,079 are inactive.

Old oil wells are scattered throughout Indonesia. Among others, 3,623 in southern Sumatera, 3,134 in East Kalimantan, 2,496 in Central Java, East Java, and Madura, 2,392 in northern Sumatera, and 208 in Papua. Seram 229 Wells [1].

The existence of thousands of old oil wells in SumatraSouth is increasingly comple ment the predicate of this city of Pale mbang as an oil-producing city. Outside the old oil wells or traditional, Palembang City also has a number of oil resources. Namely, Prabu mulih, Muara Enim, Lahat, Sekayu, Banyu Asin are managed by several contractors. Back to the problem of old oil wells, if all the wells of the wells can be maximized properly, of course South Sumatra's hopes can contribute 20 percent of total national oil production in 2017 which reached 1 million barrels per day is not impossible. Because, based on information obtained by various parties who have been involved in the world of oil and government apparatus, among others PT Pertamina EP Asset 1 Field Ramba in districts Mangunjaya, District Babat Toman, Musibanyuasin Regency (Muba) it recorded production reached 4000 BPOD. It can produce 21,000 barrels of oil per day (BPOD) for oil, while gas is at 400 million cubic feet of gas per day. However, des pite the central government's great expectation of South Sumatera Province that is expected to contribute maximally to the achievement of national oil production, it is naïve if local people only become spectators in oil management, especially old wells. The location of the illegal wells in Muba itself is overwhelming. From the data of Mining Agency (Distamben) Muba there are 800 points. The wells are located in three sub-districts, namely Sanga Desa Sub-district in Keban and Kemang Village are 400 points, Lawang Wetan Sub-District, Talang Pajering Village, 200 districts and Babat Toman Subdistrict, Sungai Angit Village is 200 points [2].

In addition to the existing 800-point wells in Muba, there are also places where oil managers or Muban societies operate where cooking crude. The location where crude oil cooking itself can be found at Central Highway (Jalinteng) Sekayu-Musirawas, can be seen drums that are on the roadside, and black smoke is soaring high that marks the place of cooking crude oil.

The definition of the local community in question is represented in the Village Unit Cooperative (KUD) and Regional Owned Enterprises (BUMD). Based on the Regulation of the Minister of Energy and Mineral Resources 
Number 1 Year 2008 concerning Guidelines for the Exploitation of Petroleum Mining on Old Wells, particularly Article 2 Paragraph (3), Petroleum Enterprises and Production as referred to in paragraph (2) shall be implemented by KUD or BUMD based on Petroleum Producing Agreement with Contractor .

Involvement of KUD and BUMD in the management of Petroleum in the old well should be done with the principles of coaching and transfer of technology, not just abort the obligation. Thus, in the long term later KUD and BUMD have adequate capability in managing the natural resources.

This is important because knowledge transfer is a mandate of the EMR Regulatory. This is as mentioned in Article 15 paragraph (2), that the Contractor shall perform technical guidance and supervision on the aspects of safety, health and environmental management as referred to in paragraph (1) to the KUD or BUMD producing petroleum. In order that, once again, the area not only inherits the extinction of its natural wealth, as well as only accept waste and pollution for the increasingly destruction of the surrounding environment.

Regulation of old well productivity opens opportunities for illegal drilling (oil theft), oil drilling activities in old wells should be done by the Cooperative or Regional Business Entity, making it easy to do supervision[3]. Oil theft is rampant until now due to the regulatory regulations that regulate the management of old wells. The regional autonomy that makes the regent / mayor a small king in the region and the cukong who became the brain of the activity also contributed to the rampant illegal activity, Minister of Energy and Mineral Resources Regulation No. 01 of 2008 concerning Guidelines for the Exploitation of Petroleum Mining on Old Wells [4], which regulates the management of old wells states that oil exploitation activities in old wells must go through concession owner's permission. Then the miners in the old wells, paid based on freight charges. The reason for freight costs that fall under the wage of labor causes, why they do creations, take oil that is not their right. In addition, what needs attention is the impact of the activity. The perpetrators of this illegal activity do not pay attention to safety equipment, so that it will affect their safety. The risk of illegal drilling is quite high. Especially the hydrocarbon element from the well that can cause fires and also environmental damage, the actors treat the wells like treating common water wells. Therefore, oil drilling activities in old wells should be done by the Cooperative or Regional Business Entity, so it is easy to be supervised, because there are responsible, permit and also certification. SKK oil and gas continues to make efforts to socialize and cooperate with the security apparatus and Contractor Cooperation Contract (KKKS) concessionaires related to the impact of oil and gas exploitation activities that do not pay attention to aspects of health and safety.

The various issues can be included in the revision of the Oil and Gas Law which is currently being drafted by the government and the House of Representatives. "So asconduct illegal drilling or illegal tapping,can be minimized. Related rules or regulations in areas that regulate the business activities of oil and gas, if it is contrary to the rules on it and used as a mode to justify illegal activities, can be revoked by the authority of the Minister of the Interior.
Note Police said that in the jurisdiction of Polda South Sumatera which became the base of illegal oil and gas activities, in 2010 there are 22 cases processed, then 30 cases in 2011, there are 90 cases in 2012 and in 2013 as many as 34 cases, 2014 occurred 28 cases, 2015 occurred 160 cases, in 2016 there were 57 cases [5].

Based on the agreement on the socialization of illegal drilling conducted by the Ministry of ESDM, Muba District Government, Muba Kodim, Muba Police and Pertamina EP on 30 August 2016 in Keluang and Mangunjaya, the controlling plan is scheduled on September 24th. Pertamina oil wells to be controlled as many as 104 wells, consisting of 84 wells in Mangunjaya and 20 wells in Kluang[6].

Many problems occur in the oil and gas sector in Indonesia. Starting from the convoluted permissions and takes hundreds of days and the number of bureaucracies that must be passed. "For drilling permits, we must go to the Ministry of ESDM, Forestry, Environment, Industry as well as BKPM, not to mention the local government, and there are still many overlapping and contradictory rules between the central and regional governments. of course in the area as well as vice versa so that there is no legal certainty in the oil and gas sector Without legal certainty, investors will be reluctant to invest in the country, whereas the oil and gas industry is an industry that requires a lot of money.

\section{PROBLEMS}

Based on the description above, the authors make the formulation of the problem as follows :

1. What is the cause of illegal drilling which is still rampant up to now?

2. What is the effect of illegal drilling that is not in accordance with Standard Operating Procedure (SOP)

\section{DISCUSSION}

\section{A. The cause of illegal drilling which is still rampant up to now}

Based on the Regulation of Minister of Energy and Mineral Resources Number 1 Year 2008 concerning the Petroleum Mining Concession Guidance On S (2) shall be implemented by KUD or BUMD based on the Petroleum Producing Agreement with the Contractor.

Involvement of KUD and BUMD in the management of Petroleu $m$ in the old well should be done with the principles of coaching and transfer of technology, not just abort the obligation. Thus, in the long term later KUD and BUMD have adequate capability in managing the natural resources.

This is important because knowledge transfer is a mandate of the EMR Regulatory. This is as mentioned in Article 15 paragraph (2), that the Contractor shall perform technical guidance and supervision on the aspects of safety, health and environmental management as referred to in paragraph (1) to the KUD or BUMD producing petroleum. In order that, once again, the area not only inherits the extinction of its natural wealth, as well as only accept waste and pollution for the increasingly destruction of the surrounding environment.

PT Pertamina (Persero) The EP and the security apparatus are currently controlling the oil wells in the 
contractor area of PT Pertamina EP Asset 1 contracts on 104 wells in two sub-districts in Musi Banyusin, South Sumatera, namely Keluang Dan Mangunjaya[6].

Restructuring activities are carried out by cementing wells and knocking down traditional rigs belonging to unscrupulous people. A total of 65 wells are controlled by cement in Keluang and Mangunjaya. But the curbing efforts did not go smoothly.

In Mangunjaya, there are 27 wells entering the red zone. Called the red zone because the people submit and submit evidence of recommendation letter from the Governor of South Sumaetra Alex Noerdin about the approval of the management of the old well in October 2013. Letter number 541.1 / 22399 / Dispertamben / 2013 contains the approval of the old oil wells by Governor Alex to Chairman KUD Karya Tambang Jaya in Mangun Jaya, Musi Banyuasin.

After coordinating, Police Chief Musi Banyuasin Adjunct Senior Commissioner Julihan Muntaha, who is in charge of coordinating operations with Pertamina to postpone the foundry permanently, discussing the recommendation letter from Governor Alex. Executive Director of Reforminer Institute Komaidi Notonegoro, said that when Alex Nurdin became regent of Musi Banyuasin, there was a local regulation related to the management of old wells in his area. According to Komaidi, then the local community can be empowered by the right through activities and mechanisms that do not violate the regulations.

Musi Banyuas in Regency Government continues to push the legality of processing old oil wells. One of the efforts made is to encourage the community of old well managers to join in the container cooperatives.

This cooperative is what we will push to get the legality of the Regent, Governor, and legality of the center through the Director General of Oil and Gas. The rules of the old oil well management are contained in the Laws, Ministerial Regulations, and Local Regulations of MusiBanyuasin.

He spreads, there are about 1,500 old wells in Musi Banyuasin, 500 of which are managed by the community. He asserted that the solution for the management of old wells can be done by the community is to form a cooperative, there is no legalize the management of old wells in Muba, the management of old wells through cooperatives, so the legality is clear. Distamben is ready to lead the legality of managing the old wells.

One of the causes of oil theft or illegal tapping activities that are still rampant up to now because of the regulation of the management of old wells. The regional autonomy that makes the Regent / Mayor a small king in the region contributed to the rampant illegal activity.

To overcome illegal drilling or illegal tapping activities, a revision of the Oil and Gas (Oil and Gas) Law is required. In the revision, the problems faced by the entrants in the upstream oil and gas sector are included, so that the revised Oil and Gas Law is a comprehensive regulation.

Then the miners in the old wells, paid based on freight charges. The reason that trans port costs fall under the wage of labor causes, why they do "creations", take oil that is not their right. In addition, what needs attention is the impact of the activity. Illegal actors are not paying attention to safety equipment, so their safety is threatened. The risk of oil drilling activities is quite high. Especially the hydrocarbon element of the well that causes fire and also environmental damage.

But the perpetrators, treating oil wells like treating common water wells. Therefore, oil drilling activities in the old wells should be done by the Cooperative or Regional Business Entity, so it is easy to be supervised, because there are people responsible, permit also certification.

SKK oil and gas, he said, has been continuously conducting socialization efforts and cooperation with the security apparatus as well as concessionaires related to the impact of oil and gas exploitation activities that do not pay attention to aspects of health and safety. The various problems can be included in the revision of the Oil and Gas Law which is now being drafted, so illegal drilling or illegal tapping activities can be minimized.

The Ministry of Energy and Mineral Resources (ESDM) affirmed that the govemor does not have the authority to is sue oil and gas mining permits to old wells. This matter has been regulated in Regulation of Minister of Energy and Mineral Resources Number 01 Year 2008 concerning Guidance of Mining Concession at Old Well. Director General of Oil and Gas at the Ministry of Energy and Mineral Resources, IGN Wiratmadja Puja, said that the Ministerial Decree No $01 / 2008$ states that mining concessions to old wells can be carried out in the working area of contractors of cooperation contracts by BUMD or Village Unit Cooperatives. However, BUMD or KUD must apply petroleum operations and production to contractors with copies to the Minister of Energy and Mineral Resources cq Director General of Oil and Gas by enclosing administrative and technical documents such as deed of establishment of KUD or BUMD and its amendment, letter of company registration, taxpayer ID number, and letter description of domicile.

Mining business on old wells can be implemented in the working area of contractor cooperation contract by BUMD or KUD after obtaining permission from ESDM minister, especially Director General of Oil and Gas. The Governor does not have the authority to is sue a permit for the mining of old oil and gas wells. Substantively, however, these policies are market-oriented and private-sector involvement, while the role and involvement of communities in determining their territories are not guaranteed and regulated in this policy. Moreover, in Law No. 4 of 2009 on Mineral and Coal Min ing, the authority to grant min ing permits is not centralized to the minister but may also be provided by the local government. This is reinforced by Law Number 32 Year 2004 regarding Regional Government. This policy further provides an opportunity for the authorities to provide the region's natural wealth to the authorities. Although in the general explanation of this law, it is said that in the framework of the creation of sustainable development, mining business activities must be carried out by taking into account the principles of environment, transparency and community participation, but if reviewed by article there is no guarantee of obligation to involve the community in the process policy making, especially in the determination of mining areas. Likewise, the policy of Law Number 22 Year 2001 on Oil and Gas, where privatization and holding on to market needs are still seen in the articles contained in this policy. It also does not recognize that society, men and women, are very important entities in every decision-making 
process, because women and men have different experience and knowledge in managing natural resources [7].

\section{B. As a result of illegal drilling that is not in accordance with the Standard Operating Procedure (SOP)}

Illegal drilling is not a complaint, the crime contained in the Oil and Gas Law is not a complaint submission so the investigation and investigation of this crime does not need to wait for a complaint[8]. Illegal drilling is categorized as ancrime extra ordinary, criminal law expert from the Islamic University of Indonesia (UII) Yogyakarta, Muzakir, said illegal drilling / illegal tapping is categorized as extraordinary crime, therefore illegal drilling law enforcement does not have to wait for the offense.

Illegal drilling of small capital but its turnover is tempting, some analysis of old well management problems that have the opportunity to occur illegal process that is environmental pollution, illegal refinery, and illegal trading involving migrant or investor community.production Illegal drilling could reach 1,000 barrels per day. Last year, the government handled illegal drilling in four areas: Blora (Central Java), Bojonegoro (East Java), Sarolangun and Batanghari (Jambi), and Musi Banyuasin (South Sumatra). The existence of this illegal well is indeed a dilemma.

The impact of illegal drilling, is that if it does not comply with the permit is to violate, the law, endanger the environment, if inappropriate management will result in fire, the fire is flooded to the victims as victims, not only property but also life. If it is forbidden, the government must be considered too loud, but if it is still excavated by the people, it would be dangerous like the burning of old oil wells in Aceh. Whereas in oil drilling, safety number one, there should be no friction at all. The result can be fatal. The problem of Pertamina itself is that to cover permanently the cost is very big, approximately Rp 2.5 billion for the closure of one well. While the number of old wells in SumateraSouth especially in Banyuasin there are 800 old wells.

Based on the author's contribution from the total amount of production cost for the old wells management, the income per day for 1 (one) well earned income is about 50-60 million per day for one month revenues around 2 billion more As for the waste alone, the waste goes out. If left unchecked it must be redundant. The waste collection result is quite large. Children come home from school to collect waste. Their income is around Rp 300 thousand per day. Drilling activities without contracts, let alone carried out on state-owned land and already existing management, namely KKKS ((kontraktor kontrak kerja sama (KKKS)) are unlawful acts. The perpetrators can be dragged with Article 52 of Law No. 22 of 2001 on Oil and Natural Gas that the threat of punishment is a six-year prison and sanctions in the form of a fine of Rp60 billion. "Illegal drilling also violates
Article 98 of Law No. 32 Year 2009 on Environmental Protection and Management", he said.

The consequence of illegal drilling is environmental damage because their activities are not in accordance with SOP especially to maintain the safety of human life. Already many victims of illegal drilling activities are the latest in Aceh as many as 18 people died from the explosion of old wells that are still in the illegal drilling activities.

\section{CONCLUSIONS AND RECOMMENDATIONS}

\section{A. Conclusion}

a. The cause of illegal drilling is still rampant up to now, for economic reasons and the necessities of life that are easily obtained from illegal drilling.

b. Due to the illegal drilling management that is not in accordance with Standard Operating Procedure (SOP), the old well management activities are based on local regulations so that the management of old wells is also overshadowed by illegal drilling activities beyond the Standard Operating Procedure (SOP) of SKK Migas.

\section{B. Recommendations}

a. Parties concerned should be able to provide training activities in the field of positive efforts so that community activities are not focused on illegal drilling.

b. Pertamina party must close the location of drilling permanently / not closed operation so that old oil wells can not be used as illegal drilling.

\section{REFERENCES}

[1] Sukandarrumidi, Et All, ENERGY TERBARUKAN, Konsep Dasar Menuju Kemandirian Energi. Yogyakarta: Gadjah Mada University Press, 2013.

[2] “No Title,” Jurnal Muamalah, vol. 3, no. 1, p. 63, 2017.

[3] "No Title." [Online]. Available: http://www.republika.co.id/berita/rol-to-campus/news-rol-tocampus-2/14/05/23/n5z8mo-empat-daerah-penghasil-minyakterbesar-di-indonesia. [Accessed: 10-Apr-2018].

[4] “No Title," Majalah Tempo Volume 37, p. 70, 2008.

[5] "HUMASPOLDA SUMSEL. 10 April2018”.

[6] "Polda Sumsel Tangan Illegal Drilling 104 Sumur Minyak," Harian Republika, 2016.

[7] MENGURAI REALTA PEMISKINAN PEREMPUAN DITENGAH KONFLIK SUMBER DAYA MANUSIA. Jakarta: Solidaritas Perempuan, 2012.

[8] M. H. Nasution, Pengamat Hukum Migas: Illegal Drilling Bukan Delik Aduan, Lakukan Penertiban Sesuai Aturan, Dunia Energi, Senin 25 June 2018. 